\title{
Emerging and Established Technologies to Increase Nitrogen Use Efficiency of Cereals
}

\author{
Juan M. Herrera ${ }^{1, *}$, Gerardo Rubio ${ }^{2}$, Lilia Levy Häner ${ }^{1}$, Jorge A. Delgado ${ }^{3}$, \\ Carlos A. Lucho-Constantino ${ }^{4}$, Samira Islas-Valdez ${ }^{5}$ and Didier Pellet ${ }^{1}$ \\ 1 Agroscope. Route de Duillier 50, Nyon 1260, Switzerland; lilia.levy@agroscope.admin.ch (L.L.H.); \\ didier.pellet@agroscope.admin.ch (D.P.) \\ 2 Instituto de Investigaciones en Biociencias Agrícolas y Ambientales (INBA-CONICET), \\ Facultad de Agronomía, Universidad de Buenos Aires, Buenos Aires C1417DSE, Argentina; \\ rubio@agro.uba.ar \\ 3 United States Department of Agriculture, Fort Collins, CO 80526, USA; Jorge.Delgado@ars.usda.gov \\ 4 Chemical Research Center, Universidad Autónoma del Estado de Hidalgo, Hidalgo 42076, Mexico; \\ luchouaeh@gmail.com \\ 5 Doctoral programme in Agricultural Chemistry, Universidad Autónoma de Madrid, Madrid 28049, Spain; \\ slapiiv@hotmail.com \\ * Correspondence: herreraj@agro.uba.ar; Tel.: +41-58-460-47-12; Fax: +41-22-362-13-25
}

Academic Editors: Francesco Montemurro and Mariangela Diacono

Received: 31 January 2016; Accepted: 13 April 2016; Published: 19 April 2016

\begin{abstract}
Nitrogen (N) fertilizers are one of the most expensive inputs in agricultural settings. Additionally, the loss of $\mathrm{N}$ increases costs, contributes to soil acidification, and causes off-site pollution of the air, groundwater and waterways. This study reviews current knowledge about technologies for $\mathrm{N}$ fertilization with potential to increase $\mathrm{N}$ use efficiency and reduce its negative effects on the environment. Classic inorganic sources such as urea and ammonium sulfate are the major sources utilized, while controlled $\mathrm{N}$ release fertilizers have not been significantly adopted for cereals and oil crops. Microorganisms, with the exception of Rhizobium sp. in soybeans, are also not widely used nowadays (e.g., plant growth-promoting bacteria and cynobacteria). The interest in implementing new $\mathrm{N}$ fertilization knowledge is stimulating the development of sensors to diagnose the $\mathrm{N}$ status and decision support systems for integrating several variables to optimize sources, rates and methods of application. Among potential new technologies we identified the incipient development of nanofertilizers, nutrient formulations to coat seeds, and recycled nutrients. Furthermore, increasing concern about the environmental consequences of $\mathrm{N}$ may facilitate the implementation of innovations outside the farm such as more effective regulations to guide $\mathrm{N}$ fertilization and methods to manufacture $\mathrm{N}$ fertilizers that are more energy-efficient and less $\mathrm{CO}_{2}$ equivalent emitting.
\end{abstract}

Keywords: nitrogen use efficiency; nanofertilizers; recycled fertilizers; slow $\mathrm{N}$ released fertilizers

\section{Introduction}

Nitrogen $(\mathrm{N})$ availability is the primary nutrient limitation for both the total food supply and protein content in food [1-3]. Nitrogen availability, uptake and translocation affects basic physiological functions associated with biomass production and grain yield [4,5]. Four major roles of $\mathrm{N}$ regarding the production of biomass and grain of cereals have been identified: (i) the establishment of photosynthetic capacity and photosynthetic activity [6-10]; (ii) the maintenance of photosynthetic activity [4,11-18]; (iii) the establishment and maintenance of sink capacity (the number and size of seeds) [16-18]; and (iv) diverse effects on the quality of crop products [19]. As a result of these effects, $\mathrm{N}$ is a fundamental 
nutrient for agriculture and global food security, and $\mathrm{N}$ fertilizers are essential to achieve the production of food for a growing human population that this planet would not otherwise be able to support.

Nitrogen fertilizers are, however, expensive inputs in cereal cropping systems [20]. Therefore, the ultimate goal of a farmer is that the target crop takes up the applied $\mathrm{N}$ with the maximum efficiency. Fertilizer $\mathrm{N}$ recovery depends on the crop, environmental conditions, and management technology; it ranges from $35 \%$ to $65 \%$ for cereals around the world (Table 1). A global outlook of major crops show that barley has the highest efficiencies recovering the applied $\mathrm{N}$, while rice show the lowest ones (Table 1). In addition, the global use of fertilizers is highly unbalanced: over-fertilization occurs in North America, Western Europe, China, and India, causing environmental pollution, while underutilization in Africa and parts of Latin America [21] causes so-called "soil mining"; i.e., the depletion of nutrients from the soil. Within the same country, whether there is over- or sub-fertilization depends also on the crop and the region; for example, in Argentina, the $\mathrm{N}$ balance associated with wheat cropping is neutral while maize cropping is associated with a negative balance [22]. Switzerland, in contrast, is an example of how regulations contributed to change from over-fertilization to a neutral N balance [23], and maize in USA is another success story associated with an increased nitrogen use efficiency (NUE); maize grain yield increased significantly during the last two decades while fertilizer application rate stayed approximately constant. Fertilizer utilization comes at an environmental cost: the loss of $\mathrm{N}$ contributes to soil acidification, and causes off-site pollution of the air, groundwater and waterways. Detailed reviews about $\mathrm{N}$ losses and its environmental consequences exist elsewhere [24,25].

The essentiality of fertilizers to secure sufficient food and the need to reduce its environmental consequences, placed the focus on NUE. This goal calls for the development of new technologies. Here, we will review the current knowledge regarding technologies to supply $\mathrm{N}$ fertilizers while increasing NUE and controlling the environmental problems resulting from $\mathrm{N}$ fertilization. We consider NUE as defined by Good et al. [26]; i.e., as the ratio between output (harvested organ) and $\mathrm{N}$ input ( $\mathrm{N}$ supplied in fertilizers and/or residual $\mathrm{N}$ in the soil). The range of technologies and agronomic practices that will be reviewed here will have a main focus on cereal production.

Table 1. Outlook of agronomic efficiency and $\mathrm{N}$ recovery of major crops around the world.

\begin{tabular}{cccc}
\hline Crop & $\begin{array}{c}\text { Agronomic Efficiency } \\
\text { (kg grain/kg N) }\end{array}$ & N Recovery $\%$ & Reference \\
\hline Barley & 9 & 63 & Delogu et al. [27] \\
Maize & $20-50$ & 37 & Rimski-Korsakov et al. [28] \\
Oilseed rape & 17 & 50 & Rathke et al. [29] \\
Rice & $10-30$ & $30-40$ & Cassman et al. [20] \\
Grain sorghum & $5-12$ & $55-65$ & Varvel and Peterson [30] \\
Soybean & 14 & 50 & Varvel and Peterson [31] \\
Sunflower & 22 & 51 & Scheiner et al. [32] \\
Wheat & 33 & $35-45$ & Cassman et al. [20] \\
\hline
\end{tabular}

\section{Literature Review}

\subsection{Classic Fertilizer Sources}

Organic fertilizers were the most popular $\mathrm{N}$ sources in the past. Their $\mathrm{N}$ content ranges between $1 \%$ and $3 \%$ and, as a consequence of their low $\mathrm{N}$ content, these sources must be applied at high rates (several tons per hectare). Manufactured fertilizers became important sources of $\mathrm{N}$ only in the last century. From 1860 to the early 1990s, anthropogenic N production globally increased from 15 to $156 \mathrm{Tg} \cdot \mathrm{Nyr}^{-1}$ [33]. Table 2 shows the main $\mathrm{N}$ sources used in the production of cereals [34,35]. 
Table 2. Nitrogen sources and their composition.

\begin{tabular}{cc}
\hline Source & Nitrogen Content (\%) \\
\hline Anhydrous ammonia & 82 \\
Aqua ammonia & $20-25$ \\
Ammonium nitrate & $33.5-34$ \\
Ammonium nitrate sulfate & 26 \\
Ammonium nitrate/lime & 20.5 \\
Ammonium sulfate & 21 \\
Ammonium thiosulfate & 12 \\
Urea-ammonium nitrate solution & $28-32$ \\
Ammonium chloride & 26 \\
Urea & 46 \\
Monoammonium phosphate & $10-11$ \\
Diammonium phosphate & 18 \\
Sodium nitrate & 16 \\
Potassium nitrate & 13 \\
Calcium nitrate & 15.5 \\
Calcium ammonium nitrate & $21-27$ \\
Sulfur-coated urea & 39 \\
Urea-formaldehyde & 38 \\
\hline
\end{tabular}

Among inorganic fertilizers, anhydrous ammonia contains the highest concentration of $\mathrm{N}(>80 \%$, Table 2), which constitutes the major advantage of using this source. In addition, it has a low cost in several countries. As it is a gas and must be pressurized for storage and handled as a liquid, it requires specialized equipment for storage, handling, and application. In addition, the effect on soil $\mathrm{pH}$ produced by this source might require lime to maintain a desired soil $\mathrm{pH}$. This later effect is not exclusively from anhydrous ammonia but from all ammoniacal sources.

Aqua ammonia (ammonium hydroxide) is composed of $25 \%$ to $29 \%$ of $\mathrm{NH}_{3}$ by weight. Transportation limits aqua $\mathrm{NH}_{3}$ production to small, local, and fluid fertilizer plants and since ammonia volatilizes quickly at temperatures above $10^{\circ} \mathrm{C}$, it is usually injected into soil depths of 50 to $100 \mathrm{~mm}$ or applied on the surface and incorporated immediately with temperatures over $10^{\circ} \mathrm{C}$.

Ammonium nitrate $\left(\mathrm{NH}_{4} \mathrm{NO}_{3}\right)$, from an agronomic point of view, is an excellent fertilizer because it combines two different $\mathrm{N}$ forms. It was reported that it allows improving the baking quality of wheat [36]. However, its low $\mathrm{N}$ content compared to other sources makes the transportation, storage, and application more expensive per unit of $\mathrm{N}$. Ammonium sulfate $\left(\left(\mathrm{NH}_{4}\right)_{2} \mathrm{SO}_{4}\right)$ is a source of both $\mathrm{N}$ and $\mathrm{S}$ that can be advantageous for acid-requiring crops (e.g., rice) and in high-pH soils (while it is undesirable in acidic soils). The main disadvantage of ammonium sulfate is its relatively low $\mathrm{N}$ content $(21 \% \mathrm{~N})$ compared to other sources. However, ammonium sulfate is popular in many parts of the world, particularly in some rice-producing areas. Monoammonium $\left(\mathrm{NH}_{4} \mathrm{H}_{2} \mathrm{PO}_{4}\right)$ and diammonium $\left(\left(\mathrm{NH}_{4}\right)_{2} \mathrm{HPO}_{4}\right)$ phosphates are more important $\mathrm{P}$ sources than $\mathrm{N}$ sources due to their relative low $\mathrm{N}$ concentration. The advantage of these globally popular fertilizers resides in their dual nutrient composition. Ammonium chloride $\left(\mathrm{NH}_{4} \mathrm{Cl}\right)$ is a low $\mathrm{N}$ source highly used for rice in Japan, China, India, and Southeast Asia. Ammonium chloride is a suitable $\mathrm{N}$ source for chloride $\left(\mathrm{Cl}^{-}\right)$responsive crops (e.g., cereals or coconut). Ammonium chloride, like ammonium sulfate, is undesirable in acid soils because it increases acidity and its use is limited to chloride-tolerant crops [35]. Ammonium bicarbonate $\left(\mathrm{NH}_{4} \mathrm{HCO}_{3}\right)$ is a source with low $\mathrm{N}$ content $(19 \% \mathrm{~N})$ that has been used almost exclusively in China [35].

Urea $\left(\mathrm{CO}\left(\mathrm{NH}_{2}\right)_{2}\right)$ is the most widely used $\mathrm{N}$ source worldwide [37]. Favorable characteristics of manufacturing, costs, handling, storage, and transport make urea a very competitive $\mathrm{N}$ source. Some of the disadvantages of urea are that its use is associated to significant ammonia volatilization losses [38] and it contains biuret, which is a phytotoxic compound that affects sensitive crops (e.g., citrus, and pineapple). Free $\mathrm{NH}_{3}$ released from urea hydrolysis also has toxic effects on germinating 
seedlings during the emergence stage. Urea-ammonium nitrate solutions (UAN) are produced from urea and ammonium nitrate and are also popular $\mathrm{N}$ solution fertilizers. One of the major drawbacks of UAN solutions is the tendency to salt-out during cold weather.

Nitrate salts such as sodium nitrate $\left(\mathrm{NaNO}_{3}\right)$, potassium nitrate $\left(\mathrm{KNO}_{3}\right)$, and calcium nitrate $\left(\mathrm{Ca}\left(\mathrm{NO}_{3}\right)_{2}\right)$ are additional $\mathrm{N}$ sources available as fertilizers. Sodium nitrate, $\mathrm{NaNO}_{3}(16 \% \mathrm{~N})$, was in the past a major source of $\mathrm{N}$ in Chile, while $\mathrm{KNO}_{3}(13 \% \mathrm{~N})$ is common in horticultural crops such as tomatoes, potatoes, tobacco, leaf vegetables, citrus fruits, peaches, and other crops. Calcium nitrate $\left(\mathrm{Ca}\left(\mathrm{NO}_{3}\right)_{2}, 15 \% \mathrm{~N}, 19 \% \mathrm{Ca}\right)$ is a common fertilizer for winter vegetable production and for foliar sprays for celery, tomatoes, and apples.

\subsection{Controlled and Slow N Release Fertilizers}

Controlled-release and slow $\mathrm{N}$ release fertilizers that minimize losses through volatilization and leaching were identified as promising tools to mitigate the negative effects of nitrous oxide $\left(\mathrm{N}_{2} \mathrm{O}\right)$ and methane emissions $\left(\mathrm{CH}_{4}\right)$ on global climate [39] and also sources that increase the recovery of applied $\mathrm{N}$ fertilizer [40]. These fertilizers release soluble $\mathrm{N}\left(\mathrm{NH}_{4}\right.$ and /or $\left.\mathrm{NO}_{3}\right)$ over several weeks or months and they increase the amount of fertilizer recovered by improving the synchronization between $\mathrm{N}$ availability and crop demand. Most products involve nitrification and urease inhibition and/or low water solubility compounds that undergo chemical and/or microbial decomposition to release N. However, the precise rate of release cannot be controlled. In such sense, some authors have distinguished controlled-release from slow-release fertilizers because they release nutrients by physical processes such as diffusion. Slow $\mathrm{N}$ release fertilizers, in contrast, are those that release nutrients by chemical or biochemical processes (e.g., aldehydes) [41,42]. The main disadvantage of slow release fertilizers is the cost, which can be four to eight times the cost of conventional fertilizers (e.g., urea). Therefore, they are primarily used in turfgrass, landscaping, ornamental, vegetable crops, greenhouse crops, and in transplantation of coniferous seedlings.

Urease inhibitors have been commercially used in some countries with some degree of success [43]. Shoji et al. [44] showed in a field experiment that the use of a controlled release fertilizer (dicyandiamide and polyolefin coated urea) instead of conventional $\mathrm{N}$ sources (UAN and ammonium polyphosphate) increased potato tuber yields and $\mathrm{N}$ use efficiency by $17 \%$ and $58 \%$, respectively. Additionally, Delgado and Mosier [45] reported that urea-dicyadiamide (DCD) significantly reduced the emissions of $\mathrm{N}_{2} \mathrm{O}$ and $\mathrm{N}$ losses to the environment. The principal purpose of using nitrification inhibitors is to keep the $\mathrm{N}$ fertilizer in the $\mathrm{NH}_{4}$ form for a longer period. Nitrification inhibitors also may reduce denitrification $\mathrm{N}$ losses by decreasing the amount of $\mathrm{NO}_{3}{ }^{-}$available for denitrification. Although nitrification inhibitors were originally developed to minimize $\mathrm{N}$ losses, they have also been proposed as a mean of altering the predominant form of $\mathrm{N}$ in the soil. Coarse textured soils with low soil organic matter are generally the most responsive to nitrification inhibitors [46]. However, the management of nitrification inhibitors is complex because it is difficult to predict when and how much $\mathrm{N}$ will be lost, while conditions favorable for $\mathrm{NO}_{3}{ }^{-}$leaching may develop after the inhibitor has degraded. In addition, a consistent yield increase from the use of nitrification inhibitors was not always observed [47]. Sulfur-coated urea has the greatest suitability where multiple applications of $\mathrm{N}$ during the growing season are needed, particularly on sandy soils under high rainfall or irrigation. It is advantageous to be used on sugarcane, pineapple, grass forages, turf, ornamentals, fruits such as cranberries and strawberries, and rice under intermittent or delayed flooding. Urea and organic compounds that inhibit the microbial activity and hydrolysis of urea rely on microbial decomposition as the primary mechanism of $\mathrm{N}$ release [48].

Urea-triazone is a controlled-release $\mathrm{N}$ compound predominantly used for foliar applications that exhibits excellent absorption properties with no toxicity to plants. Polymer-coated fertilizers (PCFs), on the other hand, are the most advanced products in controlling $\mathrm{N}$ release and improving nutrient efficiency. Because most polymer-coated products release by diffusion through a semipermeable membrane, the rate of release can be altered by composition of the coating and the coating thickness. 
For example, it is possible to alter the rate in which polymer-coated urea release $\mathrm{N}$ in time intervals that spanned from 20 to 90 days [44]. Due to the relatively high cost of these products, their use has been restricted mostly to high-value products [41].

\subsection{Microorganisms Used for Crop N Nutrition}

Several microorganisms are currently used in agriculture, and many others show potential to be used in the future. There are indications that microbial inoculants could be integrated into fertilization programs and could potentially reduce nutrient inputs [49]. There are, however, still doubts about the beneficial effect, effectiveness, negative interactions and potential risks, especially concerning the stability of the inoculants over time and under varying climatic conditions.

Microorganisms of the genus Rhizobium sp. are currently used worldwide, since they fix $\mathrm{N}_{2}$ in symbiosis with leguminous crops. The inoculation of soybean with the optimal species/strain has a significant impact on the yield and quality [50,51]. A positive response to inoculation depends on limited $\mathrm{N}$ availability and that the inoculant bacteria is present in a higher concentration and has greater capacity to compete than native populations. Interactions between Rhizobium sp. and vesicular-arbuscular mycorrhizas (VAM) in the rhizosphere of leguminous crops were reported to increase $\mathrm{N}$ uptake due to an increased availability of $\mathrm{P}[52]$ and higher $\mathrm{C}$ translocation to the $\mathrm{N}$ fixing nodules $[53,54]$.

Several experiments in different environments suggest that Azospirillum sp. inoculation may increase yield of certain cereals $[55,56]$. Azospirillum sp. have been proven to fix effectively $\mathrm{N}_{2}$, however the beneficial effects of inoculation have been mainly attributed to increased root development and thus to increased rates of water and mineral uptake. A slight yield increase of the inoculated plants over the control suggests that these inoculations combined with an integrated management strategy, might be suitable for low input systems [57].

The group of rhizospheric microorganisms known as plant growth-promoting bacteria (PGPB) include bacterial genres as Azospirillum, Azotobacter, Pseudomonas, Acetobacter, Serratia, Bacillus, and Burkholderia. PGPB have shown potential to promote vegetative growth when they are used to inoculate row or horticultural crops [58,59]. These microorganisms can have direct effects on plants like the production of growth regulators that are absorbed by the plant and stimulate the uptake of nutrients $[60,61]$. The indirect effects that PGPB has on plants are attributed to the prevention of the plant's being colonized by phytopathogens. Field grown wheat inoculated with three species of Bacillus sp. consistently increased wheat grain quality and the use efficiency of the applied fertilizer [62]. Several reports show positive effects on growth and nodulation of leguminous crops when they were co-inoculated with Rhizobium sp. and PGPB [63-65]. One explanation for the contrasting results is that the expected grain yield increases by PGPBs are usually below $5 \%$, a threshold not easy to detect with conventionally designed field experiments. There are, however, commercial inoculants available for beans, lentils, and wheat that contain the fungus Penicillium bilaii, which increase the uptake of nutrients [66]. The use of those inoculants that are effective will help to develop novel management strategies for sustainable agriculture [67].

The potential of phyllospheric microorganisms to enhance $\mathrm{N}$ nutrition is still not clear. Nevertheless, certain phyllospheric microorganisms could play a role in plant nutrition; e.g., the cyanobacteria Scytonema javanicum and Scytonema hofmanni have shown the capacity to influence the ability of legumes to fix $\mathrm{N}$ and to uptake $\mathrm{NH}_{3}$ on leaf surfaces $[68,69]$. With advances in molecular and biochemical techniques, the research on how management practices impact soil activity has been expanded and developments increasing NUE are to be expected.

\subsection{New Potential N Sources}

Biomethanation is used as a technique to produce biofuel from biomass. Fermented residues left after biomethanation processes can be used for liquid fertilizer production and as raw materials for compost. The use of fertilizers derived from biomethanation has expanded in the last years. 
In Germany, for example, more than 4000 farm anaerobic bioreactors produce 390,000 $t$ of $\mathrm{N}$ [70]. This $\mathrm{N}$ is suitable for cereals and vegetables [71] and is usually applied as liquid fertilizer [72].

Nanofertilizers (1-100 nm), on the other hand, are highly reactive due to their small size and large surface area, compared to bulk materials. As a consequence, the positive effects of nanofertilizers on crop growth may occur at lower doses than with the same nutrient supplied in its bulk from. Although research on how they can be exploited in specific crops is incipient, recent results and patent requests suggest potential useful benefits [73-76]. Concerning $N$, it is possible to hypothesize that as $\mathrm{N}$ sources that are highly soluble in water, $\mathrm{N}$ nanofertilizers once applied would be transformed in highly dynamic forms and that this characteristic would make $\mathrm{N}$ nanofertilizers particularly suitable to correct rapidly severe $\mathrm{N}$ deficiencies. Recent research suggest that their nano-dimensions allows their uptake through stomatal openings and the base of trichomes [77]. As with most new technologies, nanotechnology involves certain risks since it could have undesirable effects on non-target organisms such as plants and plant or soil microbes; thus, research for the development of nanofertilizers should be accompanied with studies addressing the environmental consequences of its use.

There is evidence that certain nutrients might be required to facilitate seed germination, especially those needed for early-required amino acids [78]. This suggest that coating seeds with nutrients could be a promising technique to improve $\mathrm{N}$ nutrition. Seeds can be coated with nutrients to allow better early contact between the emerging radicle and nutrients released from the coating formulation. Seed coating with $\mathrm{N}$ alone demonstrated greater efficacy than $\mathrm{N}$ combined with P. However, coating with P enhanced P uptake by the plant [79].

After nutrients are used by crops and consumed by humans, animals, or through industrial processes to produce energy or any other good, the waste ends up in the environment. Recapturing of nutrients either directly lost from the field or after consumption by humans and animals should become a more integral part of fertilizer production. Recycling these nutrients reduces overall losses and helps to recapture nutrients for plant uptake [49].

\subsection{Methods of Applying N Fertilizers}

The $4 \mathrm{R}$ nutrient management principles (right source, right rate, right time, and right placement) summarize the best management principles to achieve high NUE [80].

A $50 \%$ reduction in the $\mathrm{N}$ fertilizer rate in China showed that the groundwater $\mathrm{N}$ pollution could decrease by $17 \%$ with less than $5 \%$ decrease in crop production [81]. Thus, $\mathrm{N}$ rate has a strong impact on NUE. In general, the $\mathrm{N}$ source determines which method is more suitable for applying the fertilizer. In many cases, also the timing of application, as a consequence of the crop growth stage, determines the preferable application method $[82,83]$. Differences in plant $\mathrm{N}$ uptake dynamics due to the physiology of the plant species and the environmental conditions and the possibility to fractionate $\mathrm{N}$ application to meet $\mathrm{N}$ demand also orientates decisions on the application method. Some application methods may be more suitable than others or not suitable at all, depending on the timing of application. Finally, the potential methods and $\mathrm{N}$ sources that can be used are restricted to those that do not damage the crop. Table 3 shows methods of applying mineral $\mathrm{N}$ fertilizers and their corresponding $\mathrm{N}$ sources and timing of application. Boswell et al. [84] and Peterson and Fryre [83] identified source, rate, placement, and timing as the management factors that influence the $\mathrm{N}$ fertilizer recovery efficiency the most. 
Table 3. Examples of methods of $\mathrm{N}$ fertilizer application as related to $\mathrm{N}$ source and timing.

\begin{tabular}{|c|c|c|}
\hline Time of Application & N Source & Method of Application \\
\hline Pre-sowing & $\begin{array}{l}\text { Urea } \\
\text { Ammonium nitrate } \\
\text { Anhydrous ammonia } \\
\text { N solution }\end{array}$ & $\begin{array}{l}\text { Incorporated } \\
\text { Broadcast on the surface } \\
\text { Subsurface injection } \\
\text { Sprayed or dripped on the surface }\end{array}$ \\
\hline At sowing or pre-emergence & $\begin{array}{l}\text { All sources } \\
\text { All sources } \\
\text { Anhydrous ammonia } \\
\text { N solution }\end{array}$ & $\begin{array}{l}\text { In the row with the seed } \\
\text { Banded beside seed } \\
\text { Subsurface injection } \\
\text { Sprayed or dripped on the surface }\end{array}$ \\
\hline Post-emergence & $\begin{array}{l}\text { All sources } \\
\text { Anhydrous ammonia } \\
\text { Anhydrous ammonia } \\
\text { N solution }\end{array}$ & $\begin{array}{l}\text { In the inter-row (side-dress) in bands } \\
\text { In the inter-row (side-dress), subsurface injection } \\
\text { Subsurface injection } \\
\text { Foliar, sprayed on the leaves }\end{array}$ \\
\hline
\end{tabular}

Nitrogen use efficiency increases significantly by synchronizing, as much as possible, $\mathrm{N}$ availability with $\mathrm{N}$ demand. Therefore, timing the $\mathrm{N}$ application to match the maximum uptake by the crop is fundamental to maximizing uptake by the crop and minimizing $\mathrm{N}$ losses [85-88]. A precise synchronization of $\mathrm{N}$ application is especially important in environments prone to $\mathrm{N}$ leaching such as, for example, sandy soils.

Antagonism among nutrients and unsuitable $\mathrm{pH}$ levels, occur mainly in the soil, thus foliar applications allow for circumventing the restricted availability through the root. Foliar applications could also increase nutritional quality $[89,90]$ and may allow exploiting synergistic effects; a mix of $\mathrm{N}$, $\mathrm{P}, \mathrm{K}, \mathrm{Fe}, \mathrm{Cu}$ and $\mathrm{Mn}$ enhanced the nutrient content in seeds and increased yield of maize by $50 \%$ as compared to the basal application of NPK alone [91]. Due to the limited quantity of nutrients that can be delivered this way, foliar applications cannot replace basal broadcast but can be used in addition to them.

The delivery of nutrients through irrigation, i.e., fertigation, is a strategy that can be integrated into fertilizer regimes and used to adjust application rates to crop demand and, as a consequence, improve nutrient uptake efficiency [92].

Table 4 summarizes management practices that affect nitrogen nutrition.

Table 4. Management practices that affect nitrogen use efficiency from Rathke et al. [29].

\begin{tabular}{ll}
\hline Management Practice & Goal(s) as Related to N Nutrition \\
\hline Crop and crop rotation & $\begin{array}{l}\text { Increased uptake and utilization of soil available N by using N } \\
\text { efficient crops. } \\
\text { Reduction of N losses by minimizing fallow frequency and accessing } \\
\text { deeper N pools with deep rooted crops. } \\
\text { Increased N supply from mineralizable N. } \\
\text { Increased N demand by reducing the incidence of pest and diseases. }\end{array}$ \\
\hline Cover and inter-cropping & $\begin{array}{l}\text { Reduction of N losses by minimizing fallow frequency and accessing } \\
\text { deeper N pools with deep rooted crops. } \\
\text { Increased N supply from mineralizable N. }\end{array}$ \\
\hline Management of crop residues & Control of N mineralization. \\
\hline Genotype & $\begin{array}{l}\text { Increased uptake and utilization of soil available N by using N } \\
\text { efficient genotypes. }\end{array}$ \\
\hline Irrigation and crop protection & $\begin{array}{l}\text { Increased uptake and utilization of soil available N by maximizing } \\
\text { crop N demand and use. }\end{array}$ \\
\hline
\end{tabular}


Table 4. Cont.

\begin{tabular}{|c|c|}
\hline Management Practice & Goal(s) as Related to N Nutrition \\
\hline Adequate nutrition of other nutrients & $\begin{array}{l}\text { Increased uptake and utilization of soil available } \mathrm{N} \text { by maximizing } \\
\text { crop N demand and use. }\end{array}$ \\
\hline Accurate prediction of $\mathrm{N}$ need & $\begin{array}{l}\text { Increased uptake and utilization of soil available } \mathrm{N} \text { by avoiding } \\
\text { over/under application of } \mathrm{N} \text { fertilizer. }\end{array}$ \\
\hline N source & $\begin{array}{l}\text { Avoidance of } \mathrm{N} \text { losses caused by specific } \mathrm{N} \text { transformations in } \\
\text { the soil. } \\
\text { Increased } \mathrm{N} \text { physiological efficiency (yield } / \mathrm{N} \text { uptake) due to the } \\
\text { metabolism of } \mathrm{N} \text { forms }\left(\mathrm{NO}_{3} / \mathrm{NH}_{4}\right)\end{array}$ \\
\hline Timing of $\mathrm{N}$ application & $\begin{array}{l}\text { Reduction of } \mathrm{N} \text { losses and increased } \mathrm{N} \text { agronomic efficiency } \\
\text { (yield/N supply) }\end{array}$ \\
\hline $\mathrm{N}$ application method (placement) & $\begin{array}{l}\text { Reduction of } \mathrm{N} \text { losses and immobilization. } \\
\text { Improved spatial availability of soil mineral } \mathrm{N} \text {. }\end{array}$ \\
\hline Timing, intensity, and depth of tillage & Control of soil mineral N. \\
\hline
\end{tabular}

\subsection{Technologies to Diagnose Crop N Status}

Numerous factors influence crop N requirements, and low NUE occurs when the applied $\mathrm{N}$ exceeds potential demand. Since precision agriculture allows for the maximizing of NUE, the improvement of methods to diagnose $\mathrm{N}$ status of crops is an area of active research today.

The response of crops to $\mathrm{N}$ is not linear and depends on several factors. For example, under controlled conditions, the efficiency of different types of $\mathrm{N}$ fertilizers in cereals is nearly identical, but differences arise in the field as a result of interactions between $\mathrm{N}$ sources and environmental conditions (e.g., precipitation and temperature). Soil properties dictate to a large degree the responses of crops to nutrient applications; for example, $\mathrm{pH}$ can determine the extent to which a nutrient is available to plants [93], and crop response is affected by the scarcity of other nutrients such as phosphorus and potassium. Similarly, the crop rotation can change the dynamics of N, modifying the expected response to the $\mathrm{N}$ fertilizer; for example, cover crops were shown to increase the availability of $\mathrm{N}$ for the subsequent crop [94] and the duration of fallow periods affects the mineralization and water accumulation in the soil profile. In legumes, there is an additional source of $\mathrm{N}$ resulting from the symbiotic association with species of the genus Bradyrhizobium [95]. Furthermore, the type, timing, intensity, and depth of tillage has been reported to affect the response to $\mathrm{N}$ fertilization $[96,97]$. The crop choice also influences $\mathrm{N}$ fertilization and losses; Delogu et al. [27] showed that reduced $\mathrm{N}$ requirement of barley compared to wheat, makes barley a better choice to reduce ground-water pollution due to nitrate leaching in winter and early spring. Thus, $\mathrm{N}$ diagnose should integrate several sources of information and consider in-season dynamics to deliver correct $\mathrm{N}$ recommendations. Soil analysis of nitrate and ammonium at the start of the growing season is a widespread method to diagnose $\mathrm{N}$ availability in many parts of the world [98], even though results can be inconsistent due to environmental conditions and limitations on the number of samples taken.

The improvement of methods to diagnose $\mathrm{N}$ status is one of the areas of most active research in the field of $\mathrm{N}$ fertilization and management. Estimating crop $\mathrm{N}$ status during growth can be useful to adjust fertilizer levels during the growing season. Table 5 summarizes the current methods used to diagnose crop N needs during growth as identified by Muñoz-Huerta [99]. Sap nitrate tests [98,100], despite having high accuracy, are not widely applied in farms nowadays, possibly due to the effort required in sampling, preservation, extraction, dilution, and measurement [101]. In contrast, optical sensors, which do not destruct plant tissue, produce readings with generally high correlation with crop $\mathrm{N}$ status. Readings from passive ground-based sensors may be affected by soil and light conditions. Due to chlorophyll saturation, chlorophyll sensors fail to detect over-fertilization and lack the sensitivity to distinguish between different $\mathrm{N}$ treatments [102]. However, reliable correlation between reflectance and plant $\mathrm{N}$ concentration was obtained in the region of the spectrum between 480 and $870 \mathrm{~nm}$ [103], and analytical procedures that take into consideration at least two spectral indices, rather than one, 
have demonstrated capacity to better diagnose leaf $\mathrm{N}$ concentration [104]. Such is the case of the Dualex sensor that measures flavonol, anthocynin and Chlorophyll simultaneously [105].

Satellite images currently offer the possibility to cover large areas at affordable prices or for free. Initial attempts to use satellite data were limited due to drawbacks such as: (a) high cost of images; (b) interference by weather conditions (e.g., clouds); (c) slow and time-consuming image pre-processing; (d) delays between image capture and the availability of usable data [106,107]; and (e) overly spaced coverage. The high cost of images is not a limitation anymore since there have been significant reductions in their price or have become available for free. In addition, the replacement of older satellites by a new generation of satellites that can obtain images at higher resolutions is taking place. These satellites are also enlarging the constellation of satellites that screen fields, making possible to overcome other initial limitations such as overly spaced coverage. Similarly, more accurate $\mathrm{N}$ deficiency detection could be achieved in the near future by advances in the development of light and portable hyperspectral sensors [99].

With unmanned aerial vehicles becoming more affordable, research efforts are being allocated to developing sensors for drones. Indices for assessing maize $\mathrm{N}$ status based on airborne measurements were found to be as reliable as measurements taken on the ground; field level readings with a chlorophyll meter (SPAD), red edge optical reflectance $\left(R_{750} / R_{710}\right)$, and solar-induced fluorescence retrieval (SIF760) had the lowest error rates when distinguishing $\mathrm{N}$-sufficient from $\mathrm{N}$-deficient treatments $[108,109]$. Several indices based on waveband combinations of canopy reflectance have also been used: the normalized vegetation index (NDVI), the ration vegetation index (RVI), and other indices, calculated predominantly with red, green and near-infrared reflectance data of a crop canopy [110]. As hyperspectral sensors become more affordable [111], spectral indices based on differences (NDVI, green NDVI, red NDVI, red and green vegetation index (RGVI)) or ratios (red vegetation index (RVI), green vegetation index [GVI], red and green vegetation index) are calculated from averaged crop canopy reflectance readings at green $(520-600 \mathrm{~nm})$, red $(630-690 \mathrm{~nm})$, and near infrared reflectance (NIR; 760-900 nm), bandwidths e.g., [112]. Commercial reflectance sensors applied to estimate crop $\mathrm{N}$ status can be classified as passive or active, depending whether the energy source is the sun or an artificial source. Passive crop canopy reflectance sensors measure crop canopy reflectance generated by sunlight. A positive linear relationship between RVI and N uptake in winter wheat was demonstrated, as well as independence from growth stages and crop varieties. As a result, a major advantage of the RVI is that can also determine the $\mathrm{N}$ status in fields with high levels of $\mathrm{N}$ availability [112]. 
Table 5. Methods to assess N status of crops during growth.

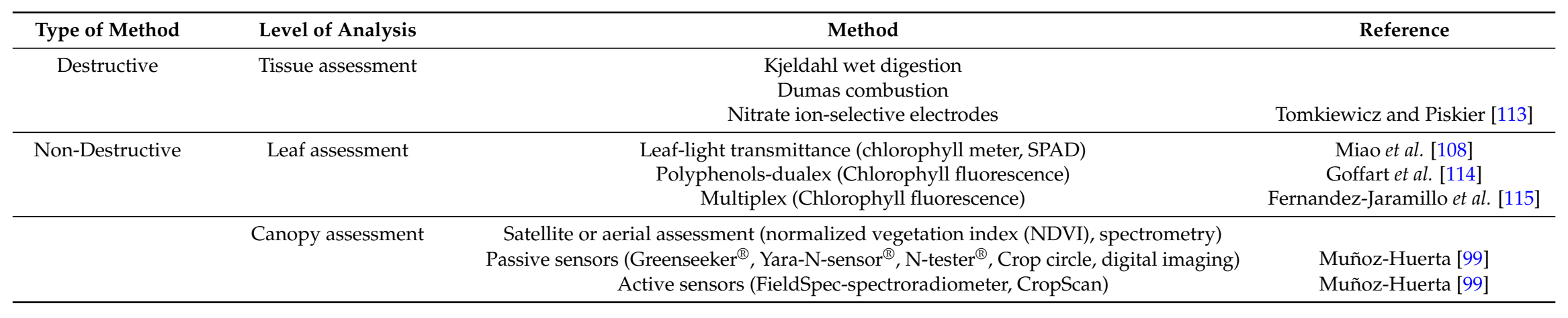




\subsection{Decision Support Systems}

Robust decision support tools were developed to help determine $\mathrm{N}$ fertilizer recommendations [116]. Crop simulation models have proven to be useful also to decide $\mathrm{N}$ applications that match crop needs [117]. The complexity associated with the fate of the applied $\mathrm{N}$ fertilizer, and the absorption and use of $\mathrm{N}$ by the crop, makes $\mathrm{N}$ fertilizer management complex and uncertain. Decision support systems are therefore fundamental in developing scenarios that predict potential consequences of $\mathrm{N}$ management practices, not only in agronomical and environmental terms but also in the context of financial constraints or opportunities.

\subsection{Outside-Farm Technologies}

Although, this review focuses on agronomical technologies, many precision conservation technologies with potential to control $\mathrm{N}$ environmental problems can be implemented outside the farm. Constructed wetlands [118] and buffer zones [119] allow for significant reduction of the environmental problems that result from $\mathrm{N}$ fertilization, especially offsite pollution of water and waterways. There are tools under development to estimate potential $\mathrm{N}$ savings. These $\mathrm{N}$ savings may be traded in future water and air quality markets [120]. Technological innovation can have a large impact, also enhancing efficiency and emission reduction, particularly at the beginning of the $\mathrm{N}$ fertilizer chain, for example, in ammonia synthesis and fertilizer manufacturing. The process of making $\mathrm{NH}_{3}$ from atmospheric $\mathrm{N}_{2}$, which is energy intensive, offers opportunities by replacing technologies to lower the $C$ emission factor from 5.1 to $2.4 \mathrm{t} \mathrm{CO}_{2}$ equivalent emitting $\mathrm{t}$. Similarly, the energy consumption of manufacturing urea could be reduced by $1.9 \mathrm{GJ} \mathrm{t} \mathrm{N}{ }^{-1}$ using more efficient technologies that are already available [121].

According to $\mathrm{Gu}$ et al. [81], technological developments play a key role in atmospheric $\mathrm{N}$ pollution control while effective policies mainly contribute to groundwater $\mathrm{N}$ pollution control. Therefore, the development and implementation of regulations is critical to orientate $\mathrm{N}$ fertilization practices that minimize the environmental impact [122]. Although varying $\mathrm{N}$ management policies have been implemented for some time in different countries, they have had variable degrees of success in achieving required food productions levels while protecting the environment. As a result, recent efforts were taken to develop tools to assess the $\mathrm{N}$ footprint of different activities [123] based on the fact that environmental effects of agricultural $\mathrm{N}$ use are ultimately a consequence of human dietary choice [124]. Figure 1 classifies the reviewed $\mathrm{N}$ technologies according to their degree of innovation and adoption. 


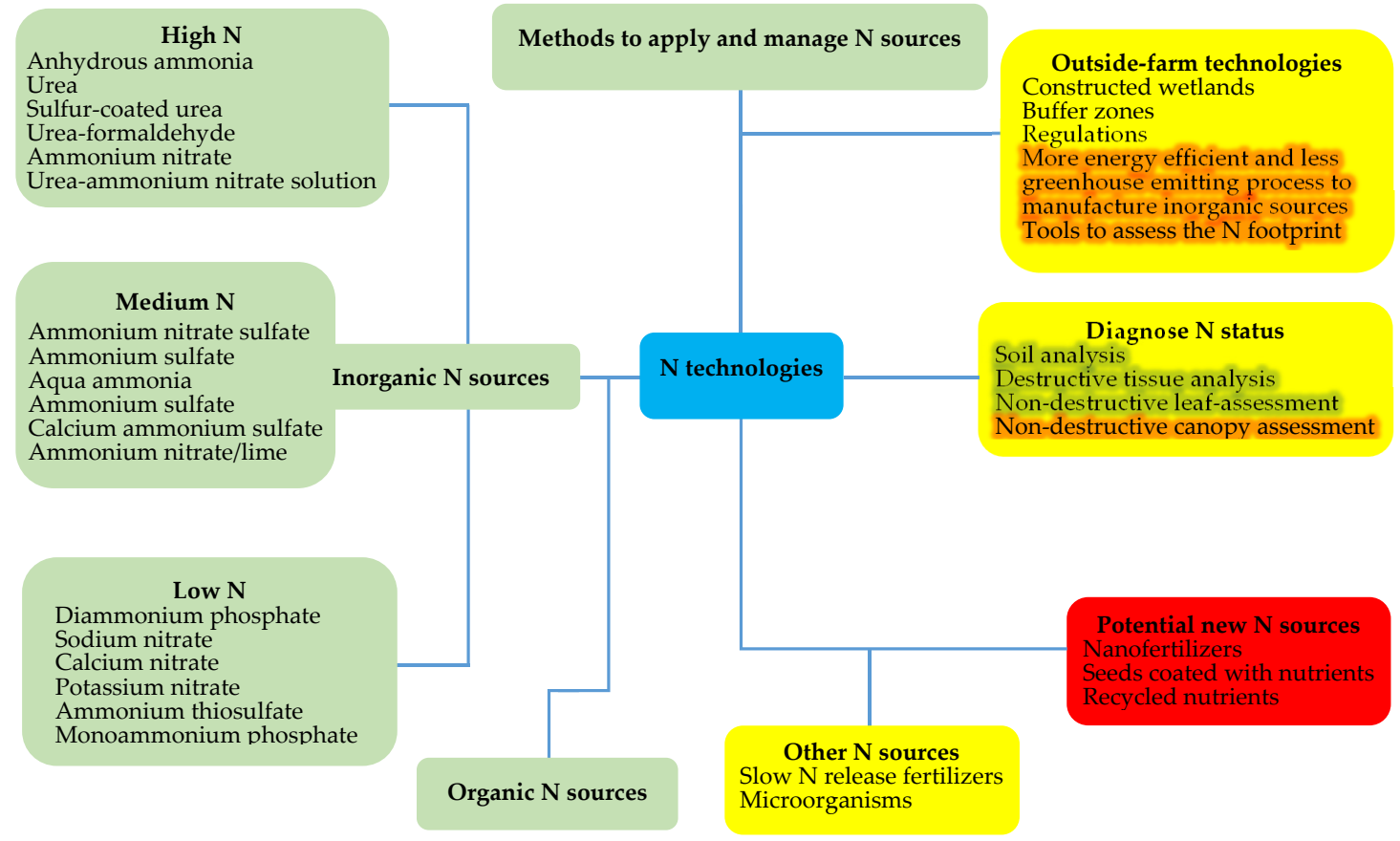

Figure 1. Mind-map of emerging and established technologies for increasing nitrogen use efficiency and reducing the environmental problems resulting from nitrogen fertilization. Red shows potential new technologies, yellow shows tested technologies with little adoption so far, and green shows established technologies.

\section{Conclusions}

Among potential new technologies we identified the incipient development of nanofertilizers, nutrient based formulations to coat seeds, and recycled nutrients. In a context of increasing concern regarding the environmental consequences of $\mathrm{N}$, innovations outside the farm such as more energy efficient and less $\mathrm{CO}_{2}$ emitting methods to manufacture $\mathrm{N}$ fertilizers, constructed wetlands and buffer zones and more effective regulations will also shape in the long-term how $\mathrm{N}$ fertilization will be done in the future.

A better understanding of the effects of $\mathrm{N}$ sources and management on the root systems of crops and how these effects relate to those on shoots is fundamental to develop better $\mathrm{N}$ fertilization products and management strategies that better synchronize soil $\mathrm{N}$ availability with crop $\mathrm{N}$ demand, and thus maximize NUE. Similarly, a more deliberate account of plant physiological processes, including the diversity of mineral nutrient uptake mechanisms, their translocation and metabolism has been suggested for the development of modern fertilizers [49]. Such considerations may significantly improve the physicochemical delivery of nutrients, their composition, amount and timing of application to meet crop uptake needs.

The fertilizer sources used nowadays have been approximately the same over the last 60 years. Throughout the world, additional funding for fertilizer research is needed to increase site-specific NUE across large, key agricultural regions of the world. Additional training and education is needed to develop future expertise across nations to implement NUE research findings on farms [37]. The development of fertilizers has been driven by identifying cheap sources of plant nutrients. Although such a characteristic is essential to produce affordable food, the observance of knowledge of plant physiology could significantly benefit the development of new fertilizer sources [49]. An example is producing fertilizers with formulations that include more than one nutrient. Although plants would preferentially transport more than one and inhibit the uptake of others $[125,126]$, synergism in nutrient uptake has been demonstrated for $\mathrm{N}[127]$ and other nutrients $[128,129]$ with proper formulations. 
The price is the main barrier to the adoption of more efficient formulations such as controlled-release fertilizers. Incentives in the form of subsidies may be an option to increase their adoption in countries where subsidies are common instruments of the agricultural policy. Subsidies could target farmers or more efficient fertilizer sources directly. Water and air quality markets, where $\mathrm{N}$ savings that result from the use of more efficient fertilizer sources are traded, could complement public policies and constitute an incentivization instrument for countries that do not subsidize agriculture.

Integrated $\mathrm{N}$ management strategies allow for the achievement of production goals while minimizing the risk of environmental pollution $[29,130,131]$. Sources of $\mathrm{N}$ and timing of application determine the most suitable method for application. The interest in implementing new knowledge about methods of application is stimulating the development of sensors to diagnose the $\mathrm{N}$ status of crops in real time throughout large areas. Decision support systems are, in this context, becoming fundamental tools to integrating several variables to optimize the source, rate and method of application.

Conflicts of Interest: The authors declare no conflict of interest.

\section{Abbreviations}

$\begin{array}{ll}\text { N } & \text { nitrogen } \\ \text { NI } & \text { nitrification inhibitor } \\ \text { PGPB } & \text { plant growth-promoting bacteria } \\ \text { NUE } & \text { nitrogen use efficiency }\end{array}$

\section{References}

1. Godfrey, D.; Hawkesford, M.J.; Powers, S.J.; Millar, S.; Shewry, P.R. Effects of crop nutrition on wheat grain composition and end use quality. J. Agric. Food Chem. 2010, 58, 3012-3021. [CrossRef] [PubMed]

2. Hawkesford, M.J. Reducing the reliance on nitrogen fertilizer for wheat production. J. Cereal Sci. 2014, 59, 276-283. [CrossRef] [PubMed]

3. Raun, W.R.; Johnson, G.V. Improving nitrogen use efficiency for cereal production. Agron. J. 1999, 91, 357-363. [CrossRef]

4. Below, F.E.; Craftsbrandner, S.J.; Harper, J.E.; Hageman, R.H. Uptake, distribution, and remobilization of n-15-labeled urea applied to maize canopies. Agron. J. 1985, 77, 412-415. [CrossRef]

5. Kaizzi, K.C.; Byalebeka, J.; Semalulu, O.; Alou, I.; Zimwanguyizza, W.; Nansamba, A.; Musinguzi, P.; Ebanyat, P.; Hyuha, T.; Wortmann, C.S. Sorghum response to fertilizer and nitrogen use efficiency in uganda. Agron. J. 2012, 104, 83-90. [CrossRef]

6. Bange, M.P.; Hammer, G.L.; Rickert, K.G. Effect of specific leaf nitrogen on radiation use efficiency and growth of sunflower. Crop Sci. 1997, 37, 1201-1208. [CrossRef]

7. Dreccer, M.F.; Schapendonk, A.; Slafer, G.A.; Rabbinge, R. Comparative response of wheat and oilseed rape to nitrogen supply: Absorption and utilisation efficiency of radiation and nitrogen during the reproductive stages determining yield. Plant Soil 2000, 220, 189-205. [CrossRef]

8. Dreccer, M.F.; Schapendonk, A.; van Oijen, M.; Pot, C.S.; Rabbinge, R. Radiation and nitrogen use at the leaf and canopy level by wheat and oilseed rape during the critical period for grain number definition. Aust. J. Plant Physiol. 2000, 27, 899-910.

9. Dreccer, M.F.; van Oijen, M.; Schapendonk, A.; Pot, C.S.; Rabbinge, R. Dynamics of vertical leaf nitrogen distribution in a vegetative wheat canopy. Impact on canopy photosynthesis. Ann. Bot. 2000, 86, 821-831. [CrossRef]

10. Muchow, R.C. Effect of nitrogen supply on the comparative productivity of maize and sorghum in a semi-arid tropical environment I. Leaf growth and leaf nitrogen. Field Crops Res. 1988, 18, 1-16. [CrossRef]

11. Boote, K.J.; Gallaher, R.N.; Robertson, W.K.; Hinson, K.; Hammond, L.C. Effect of foliar fertilization on photosynthesis, leaf nutrition, and yield of soybeans. Agron. J. 1978, 70, 787-791. [CrossRef] 
12. Harder, H.J.; Carlson, R.E.; Shaw, R.H. Leaf photosynthetic response to foliar fertilizer applied to corn plants during grain fill. Agron. J. 1982, 74, 759-761. [CrossRef]

13. Killorn, R.; Zourarakis, D. Nitrogen fertilizer management effect on corn grain yield and nitrogen uptake. J. Prod. Agric. 1992, 5, 142-148. [CrossRef]

14. Rajcan, I.; Tollenaar, M. Source: Sink ratio and leaf senescence in maize: I. Dry matter accumulation and partitioning during grain filling. Field Crops Res. 1999, 60, 245-253. [CrossRef]

15. Sinclair, T.R.; Dewit, C.T. Analysis of carbon and nitrogen limitations to soybean yield. Agron. J. 1976, 68, 319-324. [CrossRef]

16. Fischer, R.A. Irrigated spring wheat and timing and amount of nitrogen fertilizer. II. Physiology of grain yield response. Field Crops Res. 1993, 33, 57-80. [CrossRef]

17. Miralles, D.J.; Katz, S.D.; Colloca, A.; Slafer, G.A. Floret development in near isogenic wheat lines differing in plant height. Field Crops Res. 1998, 59, 21-30. [CrossRef]

18. Uhart, S.A.; Andrade, F.H. Nitrogen and carbon accumulation and removilization during grain filling in maize under different source/sink ratios. Crop Sci. 1995, 35, 183-190. [CrossRef]

19. Cooper, J.L.; Blakeney, A.B. The effect of two forms of nitrogen-fertilizer applied near anthesis on the grain quality of irrigated wheat. Aust. J. Exp. Agric. 1990, 30, 615-619. [CrossRef]

20. Cassman, K.G.; Dobermann, A.; Walters, D.T. Agroecosystems, nitrogen-use efficiency, and nitrogen management. Ambio 2002, 31, 132-140. [CrossRef] [PubMed]

21. Austin, A.T.; Bustamante, M.M.C.; Nardoto, G.B.; Mitre, S.K.; Pérez, T.; Ometto, J.P.H.B.; Ascarrunz, N.L.; Forti, M.C.; Longo, K.; Gavito, M.E.; et al. Latin America's nitrogen challenge. Science 2013, 340, 149. [CrossRef] [PubMed]

22. Alvarez, R.; Grigera, S. Analysis of soil fertility and management effects on yields of wheat and corn in the rolling pampa of Argentina. J. Agron. Crop Sci. 2005, 191, 321-329. [CrossRef]

23. Spiess, E. Nitrogen, phosphorus and potassium balances and cycles of Swiss agriculture from 1975 to 2008. Nutr. Cycl. Agroecosyst. 2011, 91, 351-365. [CrossRef]

24. Bouwman, A.F.; Boumans, L.J.M.; Batjes, N.H. Estimation of global $\mathrm{NH}_{3}$ volatilization loss from synthetic fertilizers and animal manure applied to arable lands and grasslands. Glob. Biogeochem. Cycl. 2002, 16, 1-14. [CrossRef]

25. Galloway, J.N.; Winiwarter, W.; Leip, A.; Leach, A.M.; Bleeker, A.; Erisman, J.W. Nitrogen footprints: Past, present and future. Environ. Res. Lett. 2014, 9, 115003. [CrossRef]

26. Good, A.G.; Shrawat, A.K.; Muench, D.G. Can less yield more? Is reducing nutrient input into the environment compatible with maintaining crop production? Trends Plant Sci. 2004, 9, 597-605. [CrossRef] [PubMed]

27. Delogu, G.; Cattivelli, L.; Pecchioni, N.; De Falcis, D.; Maggiore, T.; Stanca, A.M. Uptake and agronomic efficiency of nitrogen in winter barley and winter wheat. Eur. J. Agron. 1998, 9, 11-20. [CrossRef]

28. Rimski-Korsakov, H.; Rubio, G.; Lavado, R.S. Fate of the nitrogen from fertilizers in field-grown maize. Nutr. Cycl. Agroecosyst. 2012, 93, 253-263. [CrossRef]

29. Rathke, G.W.; Behrens, T.; Diepenbrock, W. Integrated nitrogen management strategies to improve seed yield, oil content and nitrogen efficiency of winter oilseed rape (Brassica napus 1.): A review. Agric. Ecosyst. Environ. 2006, 117, 80-108. [CrossRef]

30. Varvel, G.E.; Peterson, T.A. Nitrogen fertilizer recovery by grain sorghum in monoculture and rotation systems. Agron. J. 1991, 83, 617-622. [CrossRef]

31. Varvel, G.E.; Peterson, T.A. Nitrogen fertilizer recovery by soybean in monoculture and rotation systems. Agron. J. 1992, 84, 215-218. [CrossRef]

32. Scheiner, J.D.; Gutiérrez-Boem, F.H.; Lavado, R.S. Sunflower nitrogen requirement and 15n fertilizer recovery in western Pampas, Argentina. Eur. J. Agron. 2002, 17, 73-79. [CrossRef]

33. Galloway, J.N.; Dentener, F.J.; Capone, D.G.; Boyer, E.W.; Howarth, R.W.; Seitzinger, S.P.; Asner, G.P.; Cleveland, C.C.; Green, P.A.; Holland, E.A.; et al. Nitrogen cycles: Past, present and future. Biogeochemistry 2004, 70, 153-226. [CrossRef]

34. Havlin, J. Impact of management systems on fertilizer nitrogen use efficiency. In Agriculture and the Nitrogen Cycle: Assessing the Impacts of Fertilizer Use on Food Production and the Environment; Mosier, A.R., Syers, J.K., Freney, J.R., Eds.; Island Press: Washington, DC, USA, 2004; pp. 167-178.

35. Kaag, C.S.; Krishnamurthy, V.N. The fertilizer encyclopedia. Ref. User Serv. Quart. 2010, 50, 82-83. [CrossRef] 
36. Fuertes-Mendizábal, T.; González-Torralba, J.; Arregui, L.M.; González-Murua, C.; González-Moro, M.B.; Estavillo, J.M. Ammonium as sole n source improves grain quality in wheat. J. Sci. Food Agric. 2013, 93, 2162-2171. [CrossRef] [PubMed]

37. Fuglie, K.O.; Heisey, P.W.; King, J.L.; Day-Rubenstein, K.A.; Schimmelpfennig, D.E.; Wang, S.L. Research Investments and Market Structure in the Food Processing, Agricultural Input, and Biofuel Industries Worldwide; United States Department of Agriculture, Economic Research Service: Washington, DC, USA, 2011.

38. Ni, K.; Koster, J.R.; Seidel, A.; Pacholski, A. Field measurement of ammonia emissions after nitrogen fertilization-a comparison between micrometeorological and chamber methods. Eur. J. Agron. 2015, 71, 115-122. [CrossRef]

39. Bedmar, E.J.; Robles, E.F.; Delgado, M.J. The complete denitrification pathway of the symbiotic, nitrogen-fixing bacterium bradyrhizobium japonicum. Biochem. Soc. Trans. 2005, 33, 141-144. [CrossRef] [PubMed]

40. Shaviv, A. Advances in controlled release fertilizers. Adv. Agron. 2000, 71, 1-49.

41. Chien, S.H.; Prochnow, L.I.; Cantarella, H. Chapter 8 recent developments of fertilizer production and use to improve nutrient efficiency and minimize environmental impacts. Adv. Agron. 2009, 102, 267-322.

42. Du, C.; Tang, D.; Zhou, J.; Wang, H.; Shaviv, A. Prediction of nitrate release from polymer-coated fertilizers using an artificial neural network model. Biosyst. Eng. 2008, 99, 478-486. [CrossRef]

43. Upadhyay, L.S.B. Urease inhibitors: A review. Indian J. Biotechnol. 2012, 11, 381-388.

44. Shoji, S.; Delgado, J.; Mosier, A.; Miura, Y. Use of controlled release fertilizers and nitrification inhibitors to increase nitrogen use efficiency and to conserve air and water quality. Commun. Soil Sci. Plant Anal. 2001, 32, 1051-1070. [CrossRef]

45. Delgado, J.A.; Mosier, A.R. Mitigation alternatives to decrease nitrous oxides emissions and urea-nitrogen loss and their effect on methane flux. J. Environ. Qual. 1996, 25, 1105-1111. [CrossRef]

46. McCarty, G.W.; Bremner, J.M. Persistence of effects of nitrification inhibitors added to soils. Commun. Soil Sci. Plant Anal. 1990, 21, 639-648. [CrossRef]

47. Abalos, D.; Jeffery, S.; Sanz-Cobena, A.; Guardia, G.; Vallejo, A. Meta-analysis of the effect of urease and nitrification inhibitors on crop productivity and nitrogen use efficiency. Agric. Ecosyst. Environ. 2014, 189, 136-144. [CrossRef]

48. Havlin, J.L.; Beaton, J.D.; Tisdale, S.L.; Nelson, W.L. Soil Fertility and Fertilizers: An Introduction to Nutrient Management; Pearson Prentice Hall: New Jersey, NJ, USA, 2004.

49. Bindraban, P.S.; Dimkpa, C.; Nagarajan, L.; Roy, A.; Rabbinge, R. Revisiting fertilisers and fertilisation strategies for improved nutrient uptake by plants. Biol. Fertil. Soils 2015, 51, 897-911. [CrossRef]

50. Collino, D.J.; Salvagiotti, F.; Perticari, A.; Piccinetti, C.; Ovando, G.; Urquiaga, S.; Racca, R.W. Biological nitrogen fixation in soybean in Argentina: Relationships with crop, soil, and meteorological factors. Plant Soil 2015, 392, 239-252. [CrossRef]

51. Hunter, W.J. Increased nodulation of soybean by a strain of Bradyrhizobium japonicum with altered tryptophan metabolism. Lett. Appl. Microbiol. 1994, 18, 340-342. [CrossRef]

52. De Leij, F.A.A.M.; Lynch, J.M. Functional diversity of the rhizosphere. In Plant Growth-Promoting Rhizobacteria. Present, Status and Future Prospects; Ogoshi, A., Kobayashi, K., Homma, Y., Kodama, F., Kondo, N., Akino, S., Eds.; Nakanishi Printing: Sapporo, Japan, 1997; pp. 38-43.

53. Pang, P.C.; Paul, E.A. Effect of vesicular-arbuscular-mycorrhiza on ${ }^{14} \mathrm{C}$ and ${ }^{15} \mathrm{~N}$ distribution in nodulated faba beans. Can. J. Soil Sci. 1980, 60, 241-250. [CrossRef]

54. Harris, D.; Pacovsky, R.S.; Paul, E.A. Carbon economy of soybean-rhizobium-glomus associations. New Phytol. 1985, 101, 427-440. [CrossRef]

55. García de Salamone, I.E.; Funes, J.M.; Di Salvo, L.P.; Escobar-Ortega, J.S.; D'Auria, F.; Ferrando, L.; Fernandez-Scavino, A. Inoculation of paddy rice with azospirillum brasilense and pseudomonas fluorescens: Impact of plant genotypes on rhizosphere microbial communities and field crop production. Appl. Soil Ecol. 2012, 61, 196-204. [CrossRef]

56. Pereg, L.; De-Bashan, L.E.; Bashan, Y. Assessment of affinity and specificity of Azospirillum for plants. Plant Soil 2016, 399, 389-414. [CrossRef]

57. El-Sirafy, Z.M.; Woodard, H.J.; El-Norjar, E.M. Contribution of biofertilizers and fertilizer nitrogen to nutrient uptake and yield of Egyptian winter wheat. J. Plant Nutr. 2006, 29, 587-599. [CrossRef] 
58. Glick, B.R. The enhancement of plant growth by free-living bacteria. Can. J. Microbiol. 1995, 41, $109-117$. [CrossRef]

59. Patten, C.L.; Glick, B.R. Role of pseudomonas putida indoleacetic acid in development of the host plant root system. Appl. Environ. Microbiol. 2002, 68, 3795-3801. [CrossRef] [PubMed]

60. Brown, M.E. Seed and root bacterization. Annu. Rev. Phytopathol. 1974, 12, 181-197. [CrossRef]

61. Zhang, Y.P.; Pohlmann, E.L.; Roberts, G.P. Identification of critical residues in glnb for its activation of Nifa activity in the photosynthetic bacterium Rhodospirillum rubrum. Proc. Natl. Acad. Sci. USA 2004, 101, 2782-2787. [CrossRef] [PubMed]

62. Barneix, A.J.; Saubidet, M.I.; Fatta, N.; Kade, M. Effect of rhizobacteria on growth and grain protein in wheat. Agron. Sustain. Dev. 2005, 25, 505-511. [CrossRef]

63. Meyer, J.R.; Linderman, R.G. Response of subterranean clover to dual inoculation with vesicular-arbuscular mycorrhizal fungi and a plant growth-promoting rhizobacteria pseudomonas putida. Soil Biol. Biochem. 1986, 18, 185-190. [CrossRef]

64. Groppa, M.D.; Zawoznik, M.S.; Tomaro, M.L. Effect of co-incubation with Bradyrhizobium japonicum and Azospirillum brasilense on soybean plants. Eur. J. Soil Biol. 1998, 34, 75-80. [CrossRef]

65. Grimes, H.D.; Mount, M.S. Influence of pseudomonas putida on nodulation of phaseolus vulgaris. Soil Biol. Biochem. 1984, 16, 27-30. [CrossRef]

66. Leggett, M.; Newlands, N.K.; Greenshields, D.; West, L.; Inman, S.; Koivunen, M.E. Maize yield response to a phosphorus-solubilizing microbial inoculant in field trials. J. Agric. Sci. 2015, 153, 1464-1478. [CrossRef] [PubMed]

67. Vacheron, J.; Desbrosses, G.; Bouffaud, M.-L.; Touraine, B.; Moënne-Loccoz, Y.; Muller, D.; Legendre, L.; Wisniewski-Dyé, F.; Prigent-Combaret, C. Plant growth-promoting rhizobacteria and root system functioning. Front. Plant Sci. 2013, 4, 356. [CrossRef] [PubMed]

68. Freiberg, E. Microclimatic parameters influencing nitrogen fixation in the phyllosphere in a Costa Rican premontane rain forest. Oecologia 1998, 117, 9-18. [CrossRef]

69. Papen, H.; Geßler, A.; Zumbusch, E.; Rennenberg, H. Chemolithoautotrophic nitrifiers in the phyllosphere of a spruce ecosystem receiving high atmospheric nitrogen input. Curr. Microbiol. 2002, 44, 56-60. [CrossRef] [PubMed]

70. Möller, K.; Müller, T. Effects of anaerobic digestion on digestate nutrient availability and crop growth: A review. Eng. Life Sci. 2012, 12, 242-257. [CrossRef]

71. Nkoa, R.; Coulombe, J.; Desjardins, Y.; Tremblay, N. Towards optimization of growth via nutrient supply phasing: Nitrogen supply phasing increases broccoli (Brassica oleracea var. italica) growth and yield. J. Exp. Bot. 2001, 52, 821-827. [PubMed]

72. Nkoa, R. Agricultural benefits and environmental risks of soil fertilization with anaerobic digestates: A review. Agron. Sustain. Dev. 2014, 34, 473-492. [CrossRef]

73. DeRosa, M.C.; Monreal, C.; Schnitzer, M.; Walsh, R.; Sultan, Y. Nanotechnology in fertilizers. Nat. Nanotechnol. 2010, 5, 91. [CrossRef] [PubMed]

74. Ghormade, V.; Deshpande, M.V.; Paknikar, K.M. Perspectives for nano-biotechnology enabled protection and nutrition of plants. Biotechnol. Adv. 2011, 29, 792-803. [CrossRef] [PubMed]

75. Gogos, A.; Knauer, K.; Bucheli, T.D. Nanomaterials in plant protection and fertilization: Current state, foreseen applications, and research priorities. J. Agric. Food Chem. 2012, 60, 9781-9792. [CrossRef] [PubMed]

76. Servin, A.; Elmer, W.; Mukherjee, A.; De la Torre-Roche, R.; Hamdi, H.; White, J.; Bindraban, P.; Dimkpa, C. A review of the use of engineered nanomaterials to suppress plant disease and enhance crop yield. J. Nanopart. Res. 2015, 17, 1-21. [CrossRef]

77. Subramanian, K.S.; Manikandan, A.; Thirunavukkarasu, M.; Rahale, C.S. Nano-fertilizers for balanced crop nutrition. In Nanotechnologies in Food and Agriculture; Rai, M., Ribeiro, C., Mattoso, L., Duran, N., Eds.; Springer International Publishing: Heidelberg, Germany, 2015; pp. 69-80.

78. Egley, G.H. Ethylene, nitrate and nitrite interactions in the promotion of dark germination of common purslane seeds. Ann. Bot. 1984, 53, 833-840.

79. Nijënstein, H. Nutrient Seed Coating for Grasses. Available online: http://ceb.dlf.com/upload/ etsc2008_iseed-nijenstein-_final.pdf (accessed on 15 April 2016).

80. IPNI. Nutrient Stewardship. Available online: http://www.nutrientstewardship.com (accessed on 15 April 2016). 
81. Gu, B.; Zhu, Y.; Chang, J.; Peng, C.; Liu, D.; Min, Y.; Luo, W.; Howarth, R.W.; Ge, Y. The role of technology and policy in mitigating regional nitrogen pollution. Environ. Res. Lett. 2011, 6, 014011. [CrossRef]

82. Maddonni, G.A.; Ruiz, R.A.; Villarino, P.; Garcia Salomone, I. Fertilización en los cultivos para grano. In Producción de Granos, Bases Funcionales Para su Manejo; Satorre, E.H., Benech Arnold, R., de la Fuente, E.B., Miralles, D.J., Otegui, M.E., Savin, R., Eds.; Facultad de Agronomía: Buenos Aires, Argentina, 2003.

83. Peterson, G.A.; Fryre, W.W. Fertilizer nitrogen management. In Nitrogen Management and Ground Water Protection; Follett, R.F., Ed.; Elseiver: Amsterdam, The Netherlands, 1989.

84. Boswell, F.C.; Meisinger, J.J.; Case, N.L. Poduction, marketing, and use of nitrogen fertilizers. In Fertilizer Technology and Use; Engelstad, O.P., Ed.; Soil Science Society of America: Madison, WI, USA, 1985; pp. 229-292.

85. Altman, D.W.; McCuistion, W.L.; Kronstad, W.E. Grain protein percentage, kernel hardness, and grain yield of winter wheat with foliar applied urea. Agron. J. 1983, 75, 87-91. [CrossRef]

86. Deckard, E.L.; Lambert, R.J.; Hageman, R.H. Nitrate reductase-activity in corn leaves as related to yields of grain and grain protein. Crop Sci. 1973, 13, 343-350. [CrossRef]

87. Maddux, L.D.; Barnes, P.L. Effects of time and rate of applied nitrogen and nitrapyrin on irrigated corn. J. Fertil. Issues 1985, 2, 124-129.

88. Walters, D.T.; Malzer, G.L. Nitrogen management and nitrification inhibitor effects on n-15 urea.1. Yield and fertilizer use efficiency. Soil Sci. Soc. Am. J. 1990, 54, 115-122. [CrossRef]

89. Wang, J.; Mao, H.; Zhao, H.; Huang, D.; Wang, Z. Different increases in maize and wheat grain zinc concentrations caused by soil and foliar applications of zinc in loess plateau, China. Field Crops Res. 2012, 135, 89-96. [CrossRef]

90. Wang, Z.; Xie, X.; Zhao, J.; Liu, X.; Feng, W.; White, J.C.; Xing, B. Xylem- and phloem-based transport of cuo nanoparticles in maize (Zea mays L.). Environ. Sci. Technol. 2012, 46, 4434-4441. [CrossRef] [PubMed]

91. Bingham, I.J.; Blackwood, J.M.; Stevenson, E.A. Relationship between tissue sugar content, phloem import and lateral root initiation in wheat. Physiol. Plant. 1998, 103, 107-113. [CrossRef]

92. Yasuor, H.; Ben-Gal, A.; Yermiyahu, U.; Beit-Yannai, E.; Cohen, S. Nitrogen management of greenhouse pepper production: Agronomic, nutritional, and environmental implications. HortScience 2013, 48, 1241-1249.

93. Milani, N.; McLaughlin, M.J.; Stacey, S.P.; Kirby, J.K.; Hettiarachchi, G.M.; Beak, D.G.; Cornelis, G. Dissolution kinetics of macronutrient fertilizers coated with manufactured zinc oxide nanoparticles. J. Agric. Food Chem. 2012, 60, 3991-3998. [CrossRef] [PubMed]

94. Delgado, J.A.; Follett, R.F.; Shaffer, M. Simulation of nitrate-nitrogen dynamics for cropping systems with different rooting depths. Soil Sci. Soc. Am. J. 2000, 64, 1050-1054. [CrossRef]

95. Boon-Long, P.; Egli, D.B.; Leggett, J.E. Leaf $\mathrm{N}$ and photosynthesis during reproductive growth in soybeans. Crop Sci. 1983, 23, 617-620. [CrossRef]

96. Malhi, S.S.; Grant, C.A.; Johnston, A.M.; Gill, K.S. Nitrogen fertilization management for no-till cereal production in the Canadian Great Plains: A review. Soil Tillage Res. 2001, 60, 101-122. [CrossRef]

97. Zimmer, S.; Messmer, M.; Haase, T.; Piepho, H.-P.; Mindermann, A.; Schulz, H.; Habekuß, A.; Ordon, F.; Wilbois, K.-P.; Heß, J. Effects of soybean variety and bradyrhizobium strains on yield, protein content and biological nitrogen fixation under cool growing conditions in germany. Eur. J. Agron. 2016, 72, 38-46. [CrossRef]

98. Olfs, H.W.; Blankenau, K.; Brentrup, F.; Jasper, J.; Link, A.; Lammel, J. Soil- and plant-based nitrogen-fertilizer recommendations in arable farming. J. Plant Nutr. Soil Sci. 2005, 168, 414-431. [CrossRef]

99. Muñoz-Huerta, R.F.; Guevara-Gonzalez, R.G.; Contreras-Medina, L.M.; Torres-Pacheco, I.; Prado-Olivarez, J.; Ocampo-Velazquez, R.V. A review of methods for sensing the nitrogen status in plants: Advantages, disadvantages and recent advances. Sensors 2013, 13, 10823-10843. [CrossRef] [PubMed]

100. Pena-Fleitas, M.T.; Gallardo, M.; Thompson, R.B.; Farneselli, M.; Padilla, F.M. Assessing crop n status of fertigated vegetable crops using plant and soil monitoring techniques. Ann. Appl. Biol. 2015, 167, 387-405. [CrossRef] [PubMed]

101. Tremblay, N.; Fallon, E.; Ziadi, N. Sensing of crop nitrogen status: Opportunities, tools, limitations, and supporting information requirements. HortTechnology 2011, 21, 274-281.

102. Perry, E.M.; Davenport, J.R. Spectral and spatial differences in response of vegetation indices to nitrogen treatments on apple. Comput. Electron. Agric. 2007, 59, 56-65. [CrossRef] 
103. Lee, D.; Nguyen, V.; Littlefield, S. Comparison of methods for determination of nitrogen levels in soil, plant and body tissues, and water. Commun. Soil Sci. Plant Anal. 1996, 27, 783-793. [CrossRef]

104. Feng, W.; Guo, B.-B.; Wang, Z.-J.; He, L.; Song, X.; Wang, Y.-H.; Guo, T.-C. Measuring leaf nitrogen concentration in winter wheat using double-peak spectral reflection remote sensing data. Field Crops Res. 2014, 159, 43-52. [CrossRef]

105. Cerovic, Z.G.; Ben Ghozlen, N.; Milhade, C.; Obert, M.; Debuisson, S.; Le Moigne, M. Nondestructive diagnostic test for nitrogen nutrition of grapevine (Vitis vinifera L.) based on dualex leaf-clip measurements in the field. J. Agric. Food Chem. 2015, 63, 3669-3680. [CrossRef] [PubMed]

106. Goffart, J.P.; Olivier, M.; Frankinet, M. Potato crop nitrogen status assessment to improve $\mathrm{n}$ fertilization management and efficiency: Past-present-future. Potato Res. 2008, 51, 355-383. [CrossRef]

107. Wu, L.; Ogawa, Y.; Tagawa, A. Electrical impedance spectroscopy analysis of eggplant pulp and effects of drying and freezing-thawing treatments on its impedance characteristics. J. Food Eng. 2008, 87, 274-280. [CrossRef]

108. Miao, Y.X.; Mulla, D.; Randall, G.; Vetsch, J.; Vintila, R. Combining chlorophyll meter readings and high spatial resolution remote sensing images for in-season site-specific nitrogen management of corn. Precis. Agric. 2009, 10, 45-62. [CrossRef]

109. Quemada, M.; Gabriel, J.L.; Zarco-Tejada, P. Airborne hyperspectral images and ground-level optical sensors as assessment tools for maize nitrogen fertilization. Remote. Sens. 2014, 6, 2940-2962. [CrossRef]

110. Rodriguez, D.; Fitzgerald, G.J.; Belford, R.; Christensen, L.K. Detection of nitrogen deficiency in wheat from spectral reflectance indices and basic crop eco-physiological concepts. Aust. J. Agric. Res. 2006, 57, 781-789. [CrossRef]

111. Gonzalez-Dugo, V.; Hernandez, P.; Solis, I.; Zarco-Tejada, P.J. Using high-resolution hyperspectral and thermal airborne imagery to assess physiological condition in the context of wheat phenotyping. Remote. Sens. 2015, 7, 13586-13605. [CrossRef]

112. Li, F.; Gnyp, M.L.; Jia, L.; Miao, Y.; Yu, Z.; Koppe, W.; Bareth, G.; Chen, X.; Zhang, F. Estimating N status of winter wheat using a handheld spectrometer in the north China plain. Field Crops Res. 2008, 106, 77-85. [CrossRef]

113. Tomkiewicz, D.; Piskier, T. A plant based sensing method for nutrition stress monitoring. Precis. Agric. 2012, 13, 370-383. [CrossRef]

114. Goffart, J.P.; Olivier, M.; Frankinet, M. Crop nitrogen status assessment tools in a decision support system for nitrogen fertilization management of potato crops. HortTechnology 2011, 21, 282-286.

115. Fernandez-Jaramillo, A.A.; Duarte-Galvan, C.; Contreras-Medina, L.M.; Torres-Pacheco, I.; Romero-Troncoso, R.J.; Guevara-Gonzalez, R.G.; Millan-Almaraz, J.R. Instrumentation in developing chlorophyll fluorescence biosensing: A review. Sensors 2012, 12, 11853-11869. [CrossRef] [PubMed]

116. Setiyono, T.D.; Yang, H.; Walters, D.T.; Dobermann, A.; Ferguson, R.B.; Roberts, D.F.; Lyon, D.J.; Clay, D.E.; Cassman, K.G. Maize-n: A decision tool for nitrogen management in maize. Agron. J. 2011, 103, 1276-1283. [CrossRef]

117. Holzworth, D.P.; Huth, N.I.; deVoil, P.G.; Zurcher, E.J.; Herrmann, N.I.; McLean, G.; Chenu, K.; van Oosterom, E.J.; Snow, V.; Murphy, C.; et al. Apsim-evolution towards a new generation of agricultural systems simulation. Environ. Model. Softw. 2014, 62, 327-350. [CrossRef]

118. Vymazal, J. Horizontal sub-surface flow and hybrid constructed wetlands systems for wastewater treatment. Ecol. Eng. 2005, 25, 478-490. [CrossRef]

119. Castelle, A.J.; Johnson, A.W.; Conolly, C. Wetland and stream buffer size requirements-A review. J. Environ. Qual. 1994, 23, 878-882. [CrossRef]

120. Delgado, J.A.; Gagliardi, P.; Gross, C.M.; Lal, H.; McKinney, S.P.; Cover, H.; Hesketh, E.; Shaffer, M.J. A new GIS nitrogen trading tool concept for conservation and reduction of reactive nitrogen losses to the environment. Adv. Agron. 2010, 105, 117-171.

121. Zhang, W.F.; Dou, Z.X.; He, P.; Ju, X.T.; Powlson, D.; Chadwick, D.; Norse, D.; Lu, Y.L.; Zhang, Y.; Wu, L.; et al. New technologies reduce greenhouse gas emissions from nitrogenous fertilizer in china. Proc. Natl. Acad. Sci. USA 2013, 110, 8375-8380. [CrossRef] [PubMed] 
122. Van Grinsven, H.J.M.; ten Berge, H.F.M.; Dalgaard, T.; Fraters, B.; Durand, P.; Hart, A.; Hofman, G.; Jacobsen, B.H.; Lalor, S.T.J.; Lesschen, J.P.; et al. Management, regulation and environmental impacts of nitrogen fertilization in northwestern Europe under the nitrates directive: A benchmark study. Biogeosciences 2012, 9, 5143-5160. [CrossRef]

123. Stevens, C.J.; Leach, A.M.; Dale, S.; Galloway, J.N. Personal nitrogen footprint tool for the United Kingdom. Environ. Sci. Proc. Impacts 2014, 16, 1563-1569. [CrossRef] [PubMed]

124. Jobbágy, E.G.; Sala, O.E. The imprint of crop choice on global nutrient needs. Environ. Res. Lett. 2014, 9 , 084014. [CrossRef]

125. Dimkpa, C.O. Can nanotechnology deliver the promised benefits without negatively impacting soil microbial life? J. Basic Microbiol. 2014, 54, 889-904. [CrossRef] [PubMed]

126. Yang, T.J.W.; Perry, P.J.; Ciani, S.; Pandian, S.; Schmidt, W. Manganese deficiency alters the patterning and development of root hairs in Arabidopsis. J. Exp. Bot. 2008, 59, 3453-3464. [CrossRef] [PubMed]

127. Riedell, W.E. Mineral-nutrient synergism and dilution responses to nitrogen fertilizer in field-grown maize. J. Plant Nutr. Soil Sci. 2010, 173, 869-874. [CrossRef]

128. Ma, Q.; Wang, X.; Li, H.; Li, H.; Cheng, L.; Zhang, F.; Rengel, Z.; Shen, J. Localized application of $\mathrm{NH}_{4}{ }^{+}-\mathrm{N}$ plus $\mathrm{p}$ enhances zinc and iron accumulation in maize via modifying root traits and rhizosphere processes. Field Crops Res. 2014, 164, 107-116. [CrossRef]

129. Matula, J. Determination of potassium, magnesium, phosphorus, manganese and cation exchange capacity for fertilizer recommendations used by Czech union of rapeseed growers. Commun. Soil Sci. Plant Anal. 1996, 27, 1679-1691. [CrossRef]

130. Herrera, J.M.; Delgado, J.A. Integrated nitrogen management. In Advances in Nitrogen Management for Water Quality; Delgado, J.A., Follett, R.F., Eds.; Soil and Water Conservation Society: Ankeny, IA, USA, 2010.

131. Vanlauwe, B.; Descheemaeker, K.; Giller, K.E.; Huising, J.; Merckx, R.; Nziguheba, G.; Wendt, J.; Zingore, S. Integrated soil fertility management in sub-Saharan Africa: Unravelling local adaptation. SOIL Discuss. 2014, 1, 1239-1286. [CrossRef]

(C) 2016 by the authors; licensee MDPI, Basel, Switzerland. This article is an open access article distributed under the terms and conditions of the Creative Commons Attribution (CC-BY) license (http://creativecommons.org/licenses/by/4.0/). 